\title{
Analisis Model Pembelajaran Hipotesis Deduktif terhadap Keterampilan Berpikir Kritis dan Hasil Belajar Siswa pada Pokok Bahasan Gerak Lurus Berubah Beraturan
}

\author{
Affaf Husain ${ }^{*}$, Nana ${ }^{2}$ \\ 1*Mahasiswa Pendidikan Fisika Fakultas Keguruan dan Ilmu Pendidikan Universitas Siliwangi \\ ${ }^{2}$ Dosen Pendidikan Fisika Fakultas Keguruan dan Ilmu Pendididkan Universitas Siliwangi \\ *e-mail: affafhusain7@gmail.com
}

\begin{abstract}
Abstrak
Penulisan ini bertujuan untuk memperoleh gambaran pencapaian model pembelajaran hipotesis deduktif terhadap keterampilan berfikir kritis dan hasil belajar siswa pada pokok bahasan gerak lurus berubah beraturan. Penulisan ini dilatar belakangi oleh masih kurangnya keterampilan berpikir kritis dan hasil belajar siswa pada pembelajaran fisika di SMA. Oleh karena itu, perlu adanya suatu upaya untuk memecahkan masalah tersebut yaitu dengan menerapkan model pembelajaran hipotesis deduktif pada pembelajaran fisika di SMA. Metode penulisan ini menggunakan studi kepustakaan. Hasil penulisan menunjukkan bahwa penerapan model pembelajaran hipotesis deduktif dapat dijadikan suatu upaya untuk meningkatkan keterampilan berpikir kritis dan hasil belajar siswa. Model pembelajaran hipotesis deduktif diterapkan pada pembelajaran fisika SMA pada materi gerak lurus berubah beraturan dengan fase sebagai berikut: (1) fase eksplorasi, (2) fase pengenalan konsep, (3) fase aplikasi konsep.
\end{abstract}

Kata kunci: Gerak Lurus Berubah Beraturan, Hasil Belajar, Hipotesis Deduktif, Keterampilan Berpikir Kritis

\section{Abstract}

This writing aims to obtain an overview of the achievement of the deductive hypothesis learning model on critical thinking skills and student learning outcomes on the subject of uniformly changing straight motion. This writing is motivated by the lack of critical thinking skills and student learning outcomes in learning physics in high school. Therefore, there needs to be an effort to solve this problem, namely by applying the deductive hypothesis learning model in physics learning in high school. This writing method uses literature study. The results of the writing show that the application of the deductive hypothesis learning model can be used as an effort to improve critical thinking skills and student learning outcomes. The deductive hypothesis learning model is applied to high school physics learning on uniformly changing linear motion material with the following phases: (1) exploration phase, (2) concept introduction phase, (3) concept application phase.

Keywords: Uniform Movement, Learning Outcomes, Deductive Hypotheses, Critical Thinking Skills 


\section{PENDAHULUAN}

Pembelajaran fisika pada tingkat menengah atas dianggap penting untuk diajarkan. Fisika merupakan suatu wahana yang dapat digunakan untuk menumbuhkan kemampuan berpikir yang dapat digunakan untuk memecahkan masalah yang ada di kehidupan sehari-hari (Juliyanto et al., 2011). Siswa harus bisa mengembangkan kemampuan berpikir kritis dalam proses pembelajaran fisika. Pembelajaran fisika dapat berjalan secara efektif apabila siswa memiliki keterampilan berpikir kritis yang baik. Keterampilan berpikir kritis berpengaruh pada hasil belajar siswa.

Oleh karena itu, seorang guru harus mampu melakukan suatu upaya yang dapat meningkatkan keterampilan berpikir kritis siswa. Upaya yang dapat dilakukan oleh seorang guru untuk meningkatkan keterampilan berpikir kritis salah satunya dengan menerapkan model pembelajaran yang tepat. Salah satu model pembelajaran yang dapat diterapakan yaitu model pembelajaran hipotesis deduktif.

Model pembelajaran hipotesis deduktif merupakan model pembelajaran yang menghendaki adanya pengujian secara nyata dengan berbagai hipotesis untuk menjelaskan fenomena-fenomena yang ada (Saputra et al., 2016). Diterapkannya model pembelajaran hipotesis deduktif diharapkan muncul pertanyaan sebabakibat, kemudian siswa mengajukan suatu hepotesis dan hipotesis tersebut diuji melalui deduksi terhadap konsekuensi prediksi dan percobaan.

Hasil penelitian sebelumnya yang dilakukan oleh (Nina et al., 2019) dengan judul "Pengaruh Siklus Belajar Hipotes Deduktif pada Konsep Reaksi Redoks Terhadap Keterampilan Berpikir Kritis" menunjukkan bahawa keterampilan berfikir kritis siswa kelas eksperimen lebih tinggi dibandingkan dengan siswa kelas kontrol. Keterampilan berfikir kritis pada kelas eksperimen termasuk ke dalam kategori sedang dengan hasil 0,42 dan keterampilan berfikir kritis pada kelas kontrol termasuk ke dalam kategori rendah dengan hasil 0,26.

Hasil penelitian sebelumnya yang dilakukan oleh (Asfitria, 2021) dengan judul "Efektivitas Siklus Belajar Hipotesis Deduktif untuk Meningkatkan Keterampilan Berpikir Kritis Siswa Sekolah Dasar" menunjukkan bahwa peningkatan keterampilan berfikir kritis siswa pada kelas eksperimen lebih tinggi dibandingkan dengan keterampilan berfikir kritis siswa pada kelas kontrol. Rata-rata gain 
ternormalisasi keterampilan berpikir kritis siswa untuk kelas eksperimen sebesar 0,75 termasuk ke dalam kategori tinggi dan rata-rata gain ternormalisasi keterampilan berpikir kritis siswa untuk kelas kontrol sebesar 0,39 termasuk ke dalam kategori sedang.

Berdasarkan uraian di atas, tujuan dari penulisan ini adalah untuk menganalisis model pembelajaran hipotesis deduktif terhadap keterampilan berfikir kritis dan hasil belajar siswa pada pokok bahasan gerak lurus berubah beraturan.

\section{METODE}

Metode yang digunakan dalam penulisan ini yaitu metode kepustakaan dengan cara mengumpulkan sumber informasi seperti buku referensi, hasil penelitian sebelumnya misalnya artikel atau jurnal yang berkaitan dengan masalah yang akan dipecahkan. Data tersebut kemudian dianalisis kemudian disajikan dalam bentuk hasil dan pembahasan agar dibuat kesimpulan.

\section{HASIL DAN PEMBAHASAN}

\subsection{Keterampilan Berpikir Kritis}

Menurut (Ramadoan \& Sulisworo, 2018) keterampilan berfikir kritis merupakan salah satu keterampilan tingkat tinggi yang terdapat di abad 21 . Pemberian pengalaman yang bermakna kepada siswa berupa kesempatan berpendapat baik secara lisan maupun tulisan dapat mengembangkan keterampilan berpikir kritis siswa (Ramadoan \& Sulisworo, 2018).

Ketika siswa tidak dibekali dengan keterampilan berpikir kritis maka siswa akan mengalami kesulitan dalam mengolah, menilai dan menangkap informasi yang diperlukannya untuk menghadapi suatu tantangan yang ada di kehidupan sehari-hari (Saputra et al., 2016).

Keterampilan berpikir kritis mampu membantu siswa untuk mengevaluasi apa yang sudah siswa dapatkan dalam proses pembelajaran, mampu mengembangkan partisipasi siswa, mendorong sikap kerja sama, meningkatkan motivasi siswa, dan meningkatkan aktivitas siswa dengan kehidupan sehari-harinya (Nina et al., 2019).

\subsection{Hasil Belajar}


Menurut (Lovisia, 2019) hasil belajar adalah hasil yang diperoleh peserta didik setelah melaksanakan proses pembelajaran yang bisa dilihat dari hasil kemapuan peserta didik misalnya nilai tes atau nilai tugas. Hasil belajar siswa menunjukkan kemampuan dan kualitas siswa setelah melakukan proses pembelajaran. hasil belajar siswa dipengaruhi oleh beberapa faktor yaitu faktor internal dan faktor eksternal (Nurhasanah \& Sobandi, 2016). Faktor internal merupakan faktor yang berasal dari dalam diri siswa antara lain kesehatan, cacat tubuh, faktor psikologis, dan faktor kelelahan. Sedangkan faktor eksternal merupakan faktor yang berasal dari luar diri siswa misalnya faktor keluarga, sekolah dan masyarakat (Nurhasanah \& Sobandi, 2016).

\subsection{Gerak Lurus Berubah Beraturan}

Gerak lurus berubah beraturan merupakan salah satu pokok pembahasan yang terdapat di pembelajaran fisika. Gerak lurus berubah beraturan atau yang biasa di singkat GLBB merupakan gerak lurus yang memiliki kecepatan berubah secara beraturan. Suatu benda tidak selalu bergerak dengan kecepatan konstan dan melintas pada lintasan lurus (Saripudin et al., 2009).

Dalam kehidupan sehari-hari, suatu benda cenderung mempercepat dan memperlambat secara tidak beraturan. Oleh karena itu, bahwa tidak semua benda bergerak dengan kecepatan konstan. Suatu benda dikatakan bergerak lurus berubah beraturan jika benda bergerak di lintasan yang lurus dengan perubahan kecepatan yang beraturan (Saripudin et al., 2009).

\subsection{Model Pembelajaran Hipotesis Deduktif}

Secara umum hipotesis yaitu generalisasi yang artinya membuat pemikiran ilmiah eksprisit. Sedangkan deduktif adalah pemberian penjelasan tentang prinsipprinsip pelajaran, menjelaskan dengan cara menerapkan atau mencontohkan dalam siatuasi tertentu (Ramadoan \& Sulisworo, 2018). Model pembelajaran hipotesis deduktif merupakan salah satu model pembelajaran kontruktivisme yang melibatkan siswa secara aktif dalam proses belajar sehingga terjadi proses asimilasi, akomodasi, dan organisasi dalam struktur kognitif (Asfitria, 2021). 
Terdapat fase-fase pada model pembelajaran hipotesis deduktif yang dapat menyebabkan siswa mudah memahami konsep karena dalam proses pembelajaran melibatkan siswa untuk berinteraksi langsung dengan objek, fenomena, pengalaman dan lingkungan (Ramadoan \& Sulisworo, 2018). Model siklus belajar hipotesis deduktif dapat dijadikan sebagai alternatif yang baik untuk meningkatkan keterampilan berpikir kritis siswa (Asfitria, 2021).

\subsection{Model Pembelajaran Hipotesis Deduktif terhadap Keterampilan Berfikir}

Kritis Siswa pada Pokok Bahasan Gerak Lurus Berubah Beraturan

Model pembelajaran hipotesis deduktif merupakan model pembelajaran yang dapat meningkatkan keterampilan berpikir kritis dan hasil belajar siswa. setelah penulis mengkaji penelitian yang telah dilakukan sebelumnya maka penulis berencana melakukan penelitian yang berjudul "Penerapan Model Pembelajaran Hipotesis Deduktif terhadap Keterampilan Berpikir Kritis dan Hasil Belajar Siswa pada Pokok Bahasan Gerak Lurus Berubah Beraturan”.

\section{KESIMPULAN}

Model pembelajaran hipotesis deduktif merupakan model pembelajaran yang melibatkan siswa secara aktif dalam proses pembelajaran. Model pembelajaran hipotesis deduktif dapat dijadikan sebagai upaya untuk meningkatkan keterampilan berpikir kritis dan hasil belajar siswa.

\section{UCAPAN TERIMA KASIH}

Terima kasih kepada semua pihak yang telah membantu dalam penyelesaian artikel ini menjadi lebih baik.

\section{DAFTAR PUSTAKA}

Asfitria. (2021). Efektivitas Siklus Belajar Hipotesis Deduktif Untuk Meningkatkan Keterampilan Berpikir Kritis Siswa Sekolah Dasar. Jurnal Amal Pendidikan, 2(1), 47-54.

Juliyanto, E., Hartono, \& Wiyanto. (2011). Pembelajaran Fisika Untuk 
Menumbuhkan Kemampuan Berpikir Hipotetikal Deduktifpada Siswa SMA. Jurnal Pendidikan Fisika Indonesia, 7(1), 17-22. https://doi.org/10.15294/jpfi.v7i1.1063

Lovisia, E. (2019). Penerapan Model Pembelajaran Kooperatif Tipe Studentteams Achievement Division (Stad) Pada Pembelajaran Fisika Siswa Kelas X Sma Negeri 7 Lubuklinggau. Silampari Jurnal Pendidikan Ilmu Fisika, 1(1), 1-12. https://doi.org/10.31540/sjpif.v1i1.295

Nina, H., Solfarina, \& Langitasari, I. (2019). Pengaruh Siklus Belajar Hipotesis Deduktif pada Konsep Reaksi Redoks Terhadap Keterampilan Berpikir Kritis. Jurnal Profesi Keguruan, 5(1), 31-37. https://journal.unnes.ac.id/nju/index.php/jpk

Nurhasanah, S., \& Sobandi, A. (2016). Minat belajar sebagai determinan hasil belajar siswa. Jurnal Pendidikan Manajemen Perkantoran, 1(1), 128-135. https://ejournal.upi.edu/index.php/jpmanper/article/view/3264/2338

Ramadoan, N., \& Sulisworo, D. (2018). Strategi berpikir hipotetikal deduktif dalam pengembangan keterampilan berpikir kritis pada pembelajaran fisika. Quantum: Seminar Nasional Fisika, Dan Pendidikan Fisika, 25, 351-357. http://seminar.uad.ac.id/index.php/quantum/article/view/284

Saputra, H. N., Setyosari, P., \& Ulfa, S. (2016). Penerapan Model Siklus Belajar Hipotesis Deduktif untuk Meningkatkan Keterampilan Berpikir Kritis Siswa Kelas XI IPA SMA Negeri 1 Pasarwajo. Program Studi Teknologi Pembelajaran \& Psikologi Pendidikan Pascasarjana Universitas Negeri Malang, 211-218.

Saripudin, A., K, D. R., \& Duganda, A. (2009). Praktis Belajar Fisika untuk Kelas X Sekolah Menengah Atas/Madrasah Aliyah. 